\title{
Evaluation to support learning design: Lessons learned in a teacher training MOOC
}

\author{
Muriel Garreta-Domingo, Davinia Hernández-Leo \\ Universitat Pompeu Fabra, Barcelona, Spain
}

Peter B. Sloep

Open University of The Netherlands, Heerlen, The Netherlands

Designing learning opportunities is an integral part of the work of all educators. However, educators often lack the design skills and knowledge that professional designers have. We thus need more empirical research on the "demand side": how do educators design technologyenhanced learning activities, and how do we provide them with actionable knowledge that helps them design from a (human-centred) design perspective? The present study addresses both questions by analysing how in-service educators perceived and accomplished an (heuristic) evaluation design task as part of a design process to conceptualise a learning activity using information and communication technologies (ICT). Following a mixed-methods approach, we collected the heuristic evaluation protocols produced by the participants and their comments. The data shows that educators failed to perceive the task as actionable knowledge. To remedy this, we propose a set of design tasks that would provide the needed scaffolding to include the concept of design principles as part of educators' learning design processes; empowering them to assess both existing learning activities and ICT tools as well as their own designs.

\section{Introduction}

Educators are commonly seen as designers of learning opportunities (Bennett, Agostinho, \& Lockyer, 2016). They must perceive, interpret and act upon existing resources as well as devise new ones when needed; they must evaluate constraints such as those imposed by the classroom setting, balance trade-offs such as between effectiveness and efficiency, and devise strategies to pursue their specific instructional goals (Brown \& Edelson, 2003). In design parlance, educators try out, adapt and create resources to solve an educational design challenge.

However, educators often struggle to think like designers (Bencze \& Hodson, 1999; Penuel \& Gallagher, 2009). Rather, they tend to see themselves as bearers and conduits of knowledge, skills and values (GarretaDomingo, Sloep, Hernández-Leo, \& Mor, 2017b), focusing on the design of content almost in a vacuum. According to Goodyear (2015), “a teacher who doesn’t have a sense of design as a process, and who doesn’t have the conceptual tools and skills to work through a design problem in a creative but structured way, will be likely to jump straight to a solution.” (p. 31).

This rush for implementation also involves a lack of process monitoring (Boschman et al., 2014); educators do not attend much to the analysis of the success or failure of the learning activities they implement. As a result, evaluation, together with problem analysis, are the two stages most often overlooked by educators (Hoogveld, Paas, Jochems, \& Van Merriënboer, 2002).

The major aim of the field of learning design is to empower educators as designers. It does so by understanding how the intuitive processes undertaken by teachers and trainers can be made visible, shared, exposed to scrutiny and, consequently, made more effective and efficient as well as fit to incorporate information and communication tools (Laurillard, 2012; Mor, Ferguson, Wasson, 2015). However, and in spite of more than a decade of research (Dalziel et al., 2016), learning design has not widely impacted teaching practice (Bennett et al., 2016). Some argue that too much focus has been put on the "supply side" (tools, standards, software and infrastructure), too little on the "demand side” (Asensio-Pérez et al., 2017; Kali, Goodyear, \& Markauskaite, 2011). To better understand teachers’ actual design practices - the demand side - more empirical research is needed. This should result in a closer alignment between teachers' needs 
and learning design initiatives (Agostinho, Bennett, Lockyer, \& Harper, 2011). As McKenney, Kali, Markauskaite, and Voogt (2015, p. 181) point out, "to date, little has been done to capitalize on what is already understood about teachers as designers nor to draw on the wealth of literature on designers and designing outside the field of education”.

The research reported here conceptualises and analyses a design task for educators that is enacted in an authentic teacher training setting. It borrows from an existing and widely used concept and method in humancentred design and directly applies it in an educator's design process. This is aligned with the "steadily growing awareness within education that the established design professions have some methods for dealing with very complex issues, resolving conflicting requirements, reframing problems, and working with 'end users' (customers and clients; students) that are useful in educational practice” (Goodyear, 2015, p. 28). Thus, empowering educators with the methods and processes of human-centred design is a promising path towards addressing the challenges that the learning design field has. The question that remains is how to guarantee impact and efficiency through actionable knowledge that can support educators' tasks. We address this issue in a specific design step: evaluation prior to enactment.

The specific human-centred design method we selected is heuristic evaluation (HE), a usability inspection technique that does not involve users' quizzing. It is a method widely used in software development and is among the easiest to learn (Nielsen \& Mack, 1994; Ssemugabi \& de Villiers, 2010); it is also efficient, and time- and cost-effective (Albion, 1999). Nielsen et al. (1994) describe it as discount usability engineering. HE thus seems like a natural fit in the current design practices of educators: which is above all practice-driven and practice-oriented (Boschman, McKenney, \& Voogt, 2014; Doyle \& Ponder, 1977; Ertmer, 1999; Janssen, Westbroek, Doyle, \& van Driel, 2013; Matuk, Linn, \& Eylon, 2015).

This article, then, aims to tackle the following theoretical issue: does the concept of heuristics and the method of heuristic evaluation provide actionable knowledge for design in education? We focus on the micro or user level (Kali et al., 2011) in order to explore the situated nature of design cognition. The broader objective is to have a clear idea of which kinds of design thinking teachers find easy and which difficult, and which tools including methods upon which they draw - make the largest difference (Markauskaite \& Goodyear, 2009).

Our study is framed within an interpretive research paradigm (Orlikowski \& Baroudi, 1991), since it seeks to fathom the specifics and the richness of the concrete phenomena under study. We focus on the interplay between a teacher's perception of as well as his/her reflection on a design task and the designs produced. The study is exploratory, focuses on one particular authentic teacher-training context, and relies mainly on qualitative evidence (Asensio-Pérez et al., 2017). In the present study our specific research question is contextualised as follows: How does a design task based on the HE method perform in a realistic teacher training setting? This contextualisation will influence the interpretation of the data (Stake, 2010, Chapter 2.5). Our research question encompasses two topics: How do participants accomplish their design task? (Topic 1) and How does their design thinking unfold? (Topic 2). These two topics call for the collection and analysis of different types of data: the steps participants take to carry out the design task, the outcomes that participants construct as well as the comments and reflections on the task that they produce. Lessons learned through the exploration of these questions will inform the formulation of tasks along enhanced learning design processes.

In summary, we want to (1) extend and enhance the existing pool of empirical research on how to build on teacher expertise to support them in their design efforts; (2) examine the use of human-centred design methods to empower the designers' capacity of educators; and (3) inform both practice and research in the fields of learning design. Thus, the specific interest of our study lies in the insights it provides for both researchers and practitioners in the field of learning design and teacher training. The findings from this study can be relevant to researchers trying to understand how educators design but also to practitioners who are currently designing frameworks, activities and tools to enhance educators' design skills. 


\section{Methodology}

\section{Context: the HANDSON MOOC}

The context of our study is a massive open online course (MOOC) that was intended to offer a professional development opportunity for educators of all educational levels (Garreta-Domingo, Sloep, Hernández-Leo, \& Mor, 2017a). The HANDSON MOOC - implemented under a Lifelong Learning Programme project (http://www.handsonict.eu/) - was open and free. It was disseminated through the project blog, and each project partner used their networks to reach out to as many educators as possible. Following the terms used in Goodyear and Carvalho's (2014) activity-centred analysis and design (ACAD) model, the MOOC has a set, social and epistemic design dimension.

The set design of the MOOC included Moodle as the course platform and the Integrated Learning Design Environment (ILDE) as the design platform. ILDE is a web platform that helps communities of educational designers to co-create and share learning designs both from scratch or by using the templates provided (Hernández-Leo, Asensio-Pérez, Derntl, Prieto, \& Chacón, 2014). The syllabus and instructions for the course activities as well as the discussion forums - the main asynchronous communication tool used - were held in Moodle. The social design comprised peer-to-peer interaction. Four facilitators kicked off the course and guided the theoretical discussions and convergence sessions. However, participants were prompted to learn from each other by commenting on their peers' artefacts. The epistemic design was based on the Learning Design Studio (LDS), which rests on human-centred design principles (Mor \& Mogilevsky, 2013). In LDS, participating teachers engage in a design project that addresses a specific educational challenge; and facilitators - in the HANDSON MOOC, peers too - provide continuous guidance throughout the design process. Thus, participants were walked through the design of an ICT-based learning activity, that by the end of the course was supposed to be ready for enactment in their respective teaching settings. This was accomplished by completing 25 design tasks in ILDE (Figure 1). Besides carrying out these specific tasks, educators were prompted to keep a learning journal in which they could write their personal reflections on the course and the design process. In line with our research question, the focus of the present paper is on the heuristics activity (Week 3, Activity 13 in particular).

A total of 743 teachers voluntarily enrolled, and 68 educators completed the MOOC obtaining the "Designer Badge" as token of their accomplishment. The socio-demographic data of the participants was gathered through a pre-course survey, filled out by 374 educators. Of the respondents, $72 \%$ were female, $26 \%$ were male, and $2 \%$ replied N/A. Of the participants, $50 \%$ indicated they had a master's degree. The rest were distributed as follows: bachelor (24\%), initial teacher education (13\%), $\mathrm{PhD}(7 \%), \mathrm{N} / \mathrm{A}$ (6\%). Participants were mostly involved in secondary (50\%) or primary education (28\%). The percentage for higher education was $19 \%$, followed by teacher training (12\%), adult education (9\%), vocational education (5\%) and other (4\%). Most participants were from Greece (73\%) and Spain (6\%). English was the language used in the MOOC. 


\section{Design Studio for ICT-based Learning Activities - HANDSON MOOC}

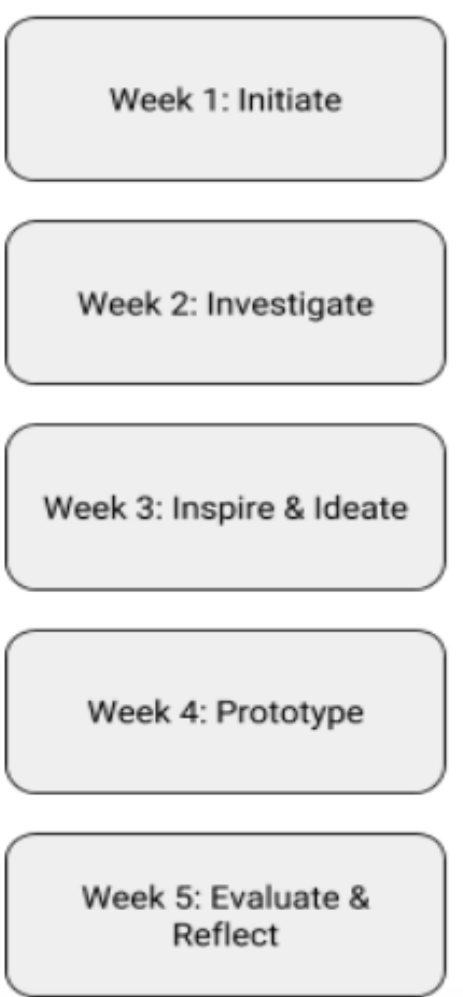

Activity 1. Welcome to the Design Studio for ICT-based Learning Activities!

Activity 2: Set up your Design Studio Journal. It is a tool for you!

Activity 3. Dream Bazaar

Activity 4. Brainstorming about ICT and education

Activity 5: Convergence session in Google Hangouts

Activity 6. Get familiar with the "personas" concept

Activity 7. Create your own personas

Activity 8: Analysing Context: Factors and Concerns

Activity 9: The objectives of your ICT-based learning activity

Activity 10: Revisit your dream and update it

Activity 11: Convergence session in Google Hangouts

Activity 12. Search for existing ICT-based learning activities

Activity 13: Define the heuristics for your design project

Activity 14. Learn about user scenarios and select an ICT tool for your activity

Activity 15. Ideate through writing a user scenario.

Activity 16: Convergence session in Google Hangouts

Figure 1. The HANDSON MOOC's learning tasks

\section{Procedures: the design task}

By Week 3, each participant had defined and refined a design challenge, created a persona card, thought about the contexts of their students, and defined the goals for their ICT-based learning activity. The instructions for the HE activity (Figure 2) focused on assessing the relevance of evaluating as early as possible in the design process; participants were invited to create their own heuristics based on the outcomes of the tasks completed by them previously, as part of their participation in the MOOC (see Figure 1).

The HE protocol template available from ILDE (Figure 3) guided participants through the details of the task. Participants were not only prompted to create their own heuristics, but they were also guided to check existing heuristics and select those adequate for their own design project.

The two different approaches to define a heuristic evaluation protocol match the two usages of heuristics in education, the most common one being to assess technology-enhanced learning tools (Reeves et al., 2002; Ssemugabi \& De Villiers, 2007, 2010). In this case, it is common to start from existing sets of heuristics and adapt them as needed. The second usage has been less explored. It sees heuristics as principles and processes that can help educators to skilfully structure their work (McKenney et al., 2015; Janssen et al., 2013). These design heuristics become, in our context, tools to increase the efficiency and effectiveness of teachers' design work. With this aim, it is more adequate to define ad hoc design principles rather than just using an existing set. Given our research question, we decided to be approach-agnostic. This allowed us to observe the phenomena in a more natural way as well as better understand how the existing knowledge of educators can be leveraged by human-centred design methods. 


\section{HANDSON Learning Design Studio ICT-Tools * Community * About course * English (en) * \\ Home DS4ICTL $>1$ June - 7 June $>$ Activity 13: Define the heuristics for your design project \\ HANDS-ON

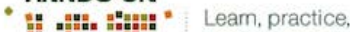 \\ teach creativity \\ "}

\section{Activity 13: Define the heuristics for your design project}

You might wonder why a course on design includes an activity on evaluation. But think - what is evaluation? In what way is it relevant to learning design? Remember - learning design is about devising activities which will get learners from where they are to where you want them to be. How will you know that your design works? Evaluation, In a nutshell, is gathering evidence that your design will achieve your objectives for your learners in their context.

To fully evaluate your learning design, you will need to implement it, test it with learners, collect data and analyse it. That's a long and expensive way to find out your mistakes! Heuristic evaluation is an alternative form of evaluation, which gives you early warnings about your design - thus avoiding costly mistakes. This method was originally invented by Jakob Neilsen in the field of usability engineering. Neilsen says:

Heuristic evaluation involves having a small set of evaluators examine the interface and judge its compliance with recognized usability principles (the "heuristics").

Recently has been adapted to help us in designing eLearning systems: the method remains the same - but the usability heuristics are joined by pedagogical heuristics. The Learning Design Grid has a page with more detail on this type of evaluation.

There are many lists of general principles but for this activity, we hope you create your own based on your personas, their contexts and your objectives.

- Go to ILDE and create your own heuristic evaluation protocol, using the template at: http://ilde.upf.edu/handson/pg/lds/new/template/HE

- Share your protocol in this forum and compare it to others'.

An important element to keep in mind is that the earlier you run an evaluation activity on your design the less costly it will be. That is why evaluating soon and often is highly recommended.

Figure 2. Screenshot from the Moodle environment

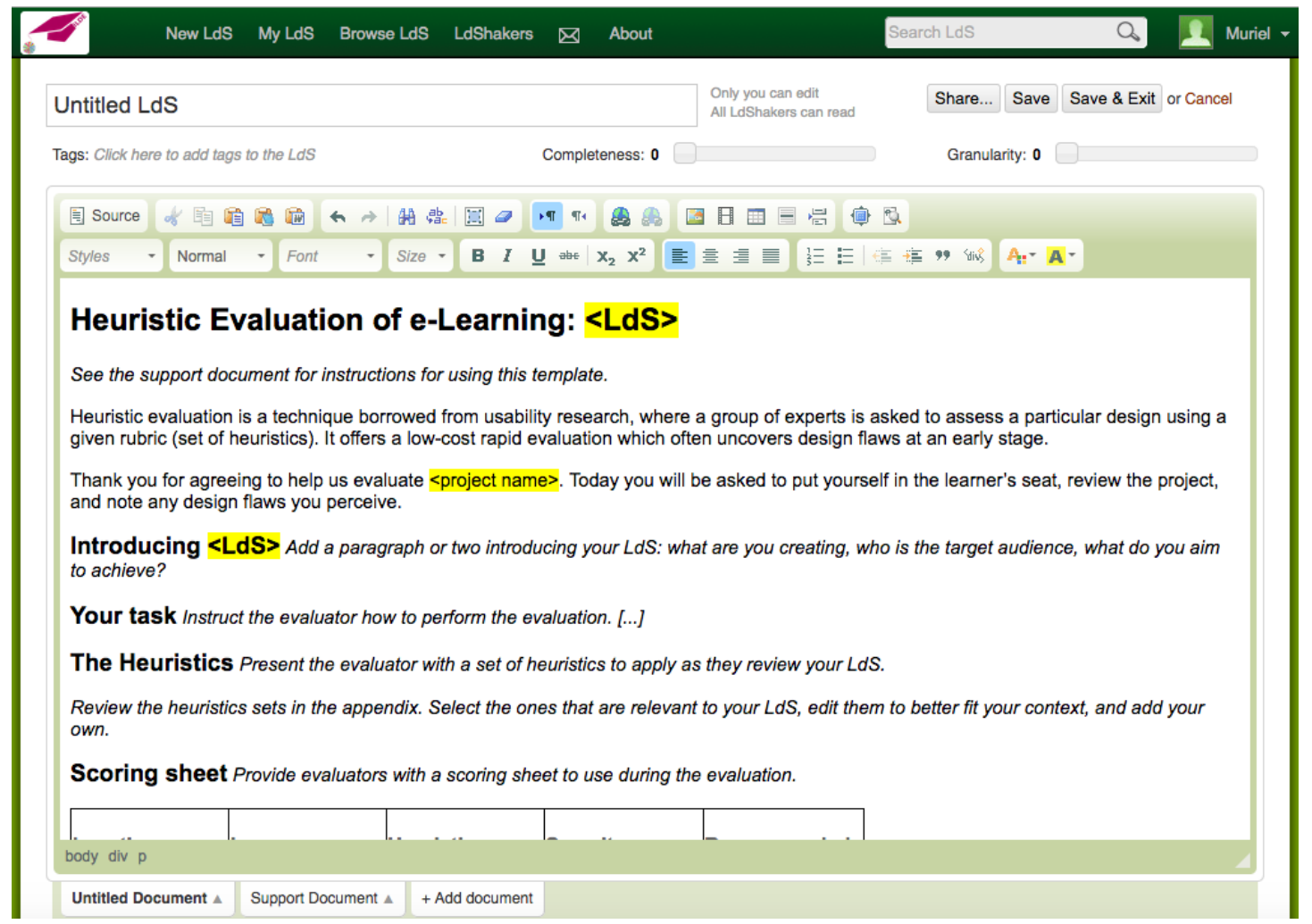

Figure 3. Heuristic evaluation template in ILDE. See https://ilde.upf.edu/handson/v/kuf for the complete template. 
Both in Moodle and ILDE, HE-supporting learning materials were available, including videos about heuristic evaluation as applied in software development and links to education-related resources. Participants had access to four sets of existing heuristics (Mor et al., 2011). Table 1 describes these sets and includes an example of an overlapping heuristic. The heuristics provided combine usability and educational heuristics.

Table 1

How typical examples of design heuristics relate to the four sets of heuristics provided to the participants

\begin{tabular}{|c|c|c|c|}
\hline Set name & Set description & $\begin{array}{l}\text { Example of a usability/user } \\
\text { interface heuristic }\end{array}$ & $\begin{array}{l}\text { Example of an } \\
\text { educational design } \\
\text { heuristic }\end{array}$ \\
\hline $\begin{array}{l}\text { User interface } \\
\text { heuristics by } \\
\text { Albion (1999) }\end{array}$ & $\begin{array}{l}\text { A combined set of } 28 \\
\text { heuristics organised in three } \\
\text { categories: interface design } \\
\text { heuristics (after Nielsen \& } \\
\text { Mack, 1994), educational } \\
\text { design heuristics (after } \\
\text { Quinn, 1996) and content } \\
\text { heuristics. Each heuristic has } \\
\text { a statement followed by a } \\
\text { short description. }\end{array}$ & $\begin{array}{l}\text { Maximises match between the } \\
\text { system and the real world. The } \\
\text { design speaks the users' } \\
\text { language rather than jargon. } \\
\text { Information appears in a } \\
\text { natural and logical order. }\end{array}$ & $\begin{array}{l}\text { Clear goals and } \\
\text { objectives. } \\
\text { The software makes it } \\
\text { clear to the learner what } \\
\text { is to be accomplished and } \\
\text { what will be gained from } \\
\text { its use. }\end{array}$ \\
\hline $\begin{array}{l}\text { User interface } \\
\text { heuristics by } \\
\text { Beale \& } \\
\text { Sharples } \\
\text { (2002) }\end{array}$ & $\begin{array}{l}\text { A usability set of nine } \\
\text { heuristics defined with a } \\
\text { brief title and a statement. }\end{array}$ & $\begin{array}{l}\text { Everyday language. Use } \\
\text { simple language, avoid } \\
\text { technical terms, follow real- } \\
\text { world conventions to make } \\
\text { things appear logical. }\end{array}$ & N/A \\
\hline $\begin{array}{l}\text { Learning } \\
\text { design } \\
\text { heuristics by } \\
\text { Ssemugabi \& } \\
\text { de Villiers } \\
\text { (2010) }\end{array}$ & $\begin{array}{l}\text { An educational set of } 20 \\
\text { heuristics organised in three } \\
\text { categories: } \\
\text { • General interface } \\
\text { usability criteria (based } \\
\text { on Nielsen \& Mack’s } \\
\text { (1994) heuristics, } \\
\text { modified for e-learning } \\
\text { context) } \\
\text { Website-specific criteria } \\
\text { Educational criteria: } \\
\text { Learner-centred } \\
\text { instructional design, } \\
\text { grounded in learning } \\
\text { theory. Each heuristic } \\
\text { has a short statement } \\
\text { and a small set of } \\
\text { related statements. }\end{array}$ & $\begin{array}{l}\text { Category 1: General interface } \\
\text { usability criteria (based on } \\
\text { Nielsen \& Macks's (1994) } \\
\text { heuristics, modified for e- } \\
\text { learning context) } \\
\text { Match between the system and } \\
\text { the real world, i.e., match } \\
\text { between designer model and } \\
\text { user model } \\
\text { - Language usage in terms } \\
\text { of phrases, symbols, and } \\
\text { concepts is similar to that } \\
\text { of users in their day-to- } \\
\text { day environment. } \\
\text { Metaphor usage } \\
\text { corresponds to real-world } \\
\text { objects/concepts. } \\
\text { Information is arranged in } \\
\text { a natural and logical } \\
\text { order. }\end{array}$ & $\begin{array}{l}\text { Category 3: Educational } \\
\text { criteria: Learner-centred } \\
\text { instructional design, } \\
\text { grounded in learning } \\
\text { theory } \\
\text { Clarity of goals, } \\
\text { objectives and outcomes } \\
\text { - There are clear } \\
\text { goals, objectives and } \\
\text { outcomes for } \\
\text { learning encounters. } \\
\text { The reason for } \\
\text { inclusion of each } \\
\text { page or document on } \\
\text { the site is clear. }\end{array}$ \\
\hline
\end{tabular}




\begin{tabular}{ll}
\hline Educational & A set of 20 educational \\
design & heuristics defined with a \\
heuristics by & short title, a statement and \\
Benson et al. & three sample questions to \\
(2001) & ask regarding the heuristic.
\end{tabular}

Match between system and
the real world. The e-
learning program interface
employs words, phrases and
concepts familiar to the
learner, rather than system-
oriented terms. Wherever
possible, it utilises real-world
conventions that make
information appear in a
natural and logical order.

Sample questions to ask yourself:

- Does the navigation and interactive design utilise metaphors that are familiar to the learner either in terms of traditional learning environments (e.g., lectures, quizzes, etc.) or in terms related to the specific content of the program?

- Is the cognitive load of the interface as low as possible to enable learners to engage with the content, tasks ... as quickly as possible?
Learning design. The interactions in the elearning program have been designed in accord with sound principles of learning theory.

Sample questions to ask yourself:

- $\quad$ Does the e-learning program provide for instructional interactions that reflect sound learning theory?

- $\quad$ Does the e-learning program engage learners in tasks that are closely aligned with the learning goals and objectives?

- Does the e-learning program inform learners of the objectives of the program and remind them of prior learning?

\section{Participants}

A total of 81 participants submitted their heuristic evaluation protocol in the discussion forum. From these, only 36 participants were kept as they provided meaningful comments on the activity in the forum or wrote a learning journal entry (either source of data is useful). The 45 protocols left out were analysed to ensure that the 36 participants selected were not atypical cases. All 81 participants proved to produce similar protocols.

Participants were coded with a number, from P1 to P36. This number corresponds to the ranking order in which participants shared their heuristic protocol to the forum: P1 denotes the first one to share, P36 the last. The participant number is relevant to inform our topics of study, as we focus not only on the artefacts produced (Topic 1) but also on how the participants' design thinking unfolded during and after task completion (Topic 2).

Participants were informed that their products (protocols, contributions to the forum) could be used for research purposes, including their publication. All were in accord, provided their products were anonymised. 


\section{Data collection}

As mentioned in the Introduction, our study is framed within an interpretative research paradigm (Orlikowski \& Baroudi, 1991). Therefore, our research design follows a concurrent, embedded, mixed-methods strategy (Creswell, 2009), relying mainly on qualitative evidence. Table 2 summarises these data sources and formats. Data is collected to inform the two topics under exploration.

Table 2

Data collected, in various formats, and topics informed

\begin{tabular}{|c|c|c|}
\hline Data source & Data format & Topic(s) informed \\
\hline $\begin{array}{l}\text { Heuristic protocols } \\
\text { (ILDE template) }\end{array}$ & $\begin{array}{l}\text { Protocols created by the participants following the } \\
\text { heuristic evaluation template (see Figure 2) } \\
\text { (qualitative) }\end{array}$ & Topic 1 \\
\hline $\begin{array}{l}\text { Discussion forum } \\
\text { (Moodle) }\end{array}$ & $\begin{array}{l}\text { Written messages on the Moodle discussion forum for } \\
\text { activity } 13 \text { (qualitative) [DisFor] }\end{array}$ & Topics 1 and 2 \\
\hline $\begin{array}{l}\text { Learning design } \\
\text { journal (ILDE) }\end{array}$ & $\begin{array}{l}\text { Written account of the participants reflections on their } \\
\text { learning process (qualitative) [LearnJ] }\end{array}$ & Topics 1 and 2 \\
\hline $\begin{array}{l}\text { Data on page views } \\
\text { (Google Analytics) }\end{array}$ & $\begin{array}{l}\text { Data based on the number of artefact views and their } \\
\text { characteristics (quantitative) }\end{array}$ & Topic 1 \\
\hline $\begin{array}{l}\text { Weekly survey } \\
\text { questions (Google } \\
\text { Forms) }\end{array}$ & $\begin{array}{l}\text { The weekly surveys were sent out at the end of each } \\
\text { week and included closed questions on the level of } \\
\text { difficulty of the course activities (quantitative). }\end{array}$ & Topics 1 and 2 \\
\hline
\end{tabular}

\section{Data analysis}

Given the two main data sources - artefacts produced and comments and reflections - two different data analysis strategies were applied (Table 2).

The heuristic protocols produced by the participants were analysed against the existing sets of heuristics provided. The analysis focused on finding which patterns emerged from these artefacts. We employed a twostep approach: what overall form did the protocols have and which were these heuristics? For the first step, the analysis aimed to see if the participant had used an existing set of heuristics to start with and what, if any, these were. The second step - following a semi-quantitative approach - consisted of listing all existing heuristics provided and noting which ones were included in the protocols the participants produced.

The data gathered from [DisFor] and [LearnJ] were analysed through thematic analysis (see Table 3). Here the epistemological aim is to give voice to the participants, to unravel the reality of the prospective teacher experience by identifying the patterns of meaning in their accounts (Braun \& Clarke, 2006). As Braun and Clarke recommend, the entire data set was scanned various times, with the subsequent analysis involving becoming familiar with the data (responses), generating and reviewing codes, searching for themes, and reviewing themes.

Finally, the quantitative data concern responses to the questionnaires that were sent out (Table 2). The two questions we focus on are how useful and difficult the participants considered the activities of Week 3, in particular the heuristic evaluation (activity 13). Possible answers were "very useful", "useful", "not applicable", "kind of useful”, "not useful” and "very simple”, "simple”, "just about right”, "difficult” and "very difficult", respectively. Week 1 did not include the question about difficulty. Responses were grouped in three main categories. Note that the presentation of the survey responses does not differentiate between the 36 participants. 
Table 3

Qualitative analysis of the data collected from the participants

\begin{tabular}{|c|c|c|c|}
\hline Themes & Codes & Example quote & Participant \\
\hline $\begin{array}{l}\text { Lack of } \\
\text { understanding of } \\
\text { the activity }\end{array}$ & $\begin{array}{l}\text { “struggle”, “difficult”, } \\
\text { “effort”, “demanding”, } \\
\text { “complicated” }\end{array}$ & $\begin{array}{l}\text { "June } 4 \text { - I finally wrote my Heuristic } \\
\text { Evaluation. I found this activity a little } \\
\text { difficult. It was not so easy for me to } \\
\text { understand the task." [LearnJ] }\end{array}$ & P16 \\
\hline $\begin{array}{l}\text { Uncertainty } \\
\text { towards the } \\
\text { produced } \\
\text { artefacts }\end{array}$ & $\begin{array}{l}\text { "I did my best”, “I’m } \\
\text { not sure that what I did } \\
\text { is correct”, "Did I do it } \\
\text { in the appropriate way?” }\end{array}$ & $\begin{array}{l}\text { "I have followed the instructions of our } \\
\text { facilitators and read the protocol of my peers. } \\
\text { Here you can see my heuristics. I am anxious } \\
\text { about the comments. Did I do it in the } \\
\text { appropriate way? I would appreciate your } \\
\text { opinion.” [DisFor] }\end{array}$ & P20 \\
\hline $\begin{array}{l}\text { Positive towards } \\
\text { the HE method }\end{array}$ & $\begin{array}{l}\text { "A very useful tool.” } \\
\text { "It's a great idea to } \\
\text { review learning designs } \\
\text { before you use them.”, } \\
\text { "I have to keep in my } \\
\text { mind the heuristics } \\
\text { when designing the } \\
\text { learning activity.” }\end{array}$ & $\begin{array}{l}\text { "It was very interesting to read about the } \\
\text { heuristics, I have never heard about them and } \\
\text { now I know how important they are and I } \\
\text { think about situations when I did not } \\
\text { understand something or I did not find what I } \\
\text { want, maybe there were something wrong } \\
\text { with the whole concept." [LearnJ] }\end{array}$ & P35 \\
\hline
\end{tabular}

\section{Results}

The Results section consists of three subsections. The first one focuses on how participants approached the HE design task (Topics 1 and 2). The second one covers the analysis of the artefacts that participants produced (Topic 1). The third addresses how the design thinking of participants unfolded (Topic 2).

\section{How participants approached their task (Topics 1 and 2)}

According to the epistemic and social design of the MOOC, participants used two different sources to inform their work on the evaluation task. First, they followed the heuristic task instructions by reading the provided materials. Thus, the existing sets of heuristics were a key starting point for them (more evidence on this in the next subsection). Second, they followed the social design approach of the MOOC and looked at each other's artefacts and also commented on them. See Tables 4 and 5.

Table 4 consists of some of the participants' explanations on how they went on with the HE design task ([LearnJ] [DisFor], Table 2). This data shows a trend in the way participants approached the design task: participants felt the need to look at examples of what they were asked to do in order to produce their own protocols. Thus, neither the set of existing heuristics provided nor the prompt to define their own heuristics were sufficiently actionable (knowledge) to allow them to accomplish their task. 
Table 4

Examples of how participants expressed they had accomplished the task

\begin{tabular}{|c|c|}
\hline Participant & Example \\
\hline $\mathrm{P} 28$ & $\begin{array}{l}\text { I searched through the sets of heuristics given, and chose those that I thought were relevant to } \\
\text { everything my learning activities are meant to be like ideally/everything they should contain. } \\
\text { [LearnJ] }\end{array}$ \\
\hline P10 & $\begin{array}{l}\text { Heuristic evaluation is an alternative form of evaluation. After searching and reading some } \\
\text { articles in regards to the principles of an evaluation - The Learning Design Grid this type of } \\
\text { evaluation and Nielsen, I came up with my evaluation protocol. } \\
\text { [LearnJ] }\end{array}$ \\
\hline P23 & $\begin{array}{l}\text { I saw your [PARTICIPANT'S NAME, P6] work and it is very good! I also studied your } \\
\text { evaluation sheet and with your permission I will use it as a prototype for my evaluation sheet! } \\
\text { Excellent work! Bravo! Thank you for the inspiration! } \\
\text { [DisFor] }\end{array}$ \\
\hline P1 & $\begin{array}{l}\text { You did very well, [PARTICIPANT'S NAME, P3]! } \\
\text { [DisFor] }\end{array}$ \\
\hline P3 & $\begin{array}{l}\text { Thank you [PARTICIPANT'S NAME, P1]. There are no words to say for you. You learn } \\
\text { [teach, authors' insertion] me many things. You did an excellent job. } \\
\text { [DisFor] }\end{array}$ \\
\hline
\end{tabular}

The quantitative data confirm the qualitative data (Table 5). In the absence of more scaffolding for this design task, educators looked for guidance in the first protocols that were shared by fellow participants. The first two artefacts publicly shared in the discussion forum were the ones that received most views: P1's design was the one most viewed by the participants.

Table 5

Influence of first movers on remaining participants

\begin{tabular}{|c|c|c|c|c|c|c|c|}
\hline Participant & $\begin{array}{l}\text { Date of publication } \\
\text { in forum }\end{array}$ & $\begin{array}{l}\text { Date of update } \\
\text { in forum }\end{array}$ & Views & Users & Sessions & $\begin{array}{l}\text { Average } \\
\text { duration }\end{array}$ & $\begin{array}{l}\text { Returning } \\
\text { visitors }\end{array}$ \\
\hline $\mathrm{P} 1$ & $\begin{array}{l}\text { Saturday, } 31 \text { May } \\
\text { 2014, 6:09 PM - } \\
\text { This was the first } \\
\text { protocol shared in } \\
\text { the forum }\end{array}$ & $\begin{array}{l}\text { Tuesday, } 3 \text { June } \\
\text { 2014, 8:54 PM }\end{array}$ & 3727 & 102 & 170 & $0: 40: 53$ & $92.4 \%$ \\
\hline $\mathrm{P} 2$ & $\begin{array}{l}\text { Saturday, } 31 \text { May } \\
\text { 2014, 10:08 PM }\end{array}$ & & 1802 & 65 & 85 & $0: 40: 07$ & $94.1 \%$ \\
\hline P10 & $\begin{array}{l}\text { Monday, } 2 \text { June } \\
\text { 2014, 9:23 PM }\end{array}$ & $\begin{array}{l}\text { Tuesday, } 3 \text { June } \\
\text { 2014, 1:01 PM }\end{array}$ & 1154 & 35 & 42 & $0: 46: 45$ & $88.1 \%$ \\
\hline P8 & $\begin{array}{l}\text { Monday, } 2 \text { June } \\
\text { 2014, 10:21 AM } \\
\text { (the link in this post } \\
\text { did not work) }\end{array}$ & $\begin{array}{l}\text { Monday, } 2 \text { June } \\
\text { 2014, 10:21 AM } \\
\text { (with link } \\
\text { working) }\end{array}$ & 1287 & 40 & 55 & $0: 40: 20$ & $94.5 \%$ \\
\hline P7 & $\begin{array}{l}\text { Monday, } 2 \text { June } \\
\text { 2014, 8:32 PM }\end{array}$ & & 909 & 30 & 38 & $0: 42: 46$ & $89.5 \%$ \\
\hline
\end{tabular}




\section{What participants produced (Topic 1)}

As mentioned, participants were given two apparently - but purposely - divergent indications on how to tackle their design task. At that stage in the design process, the objectively most useful output of the heuristics design task was a set of self-defined heuristics to synthesise what they had already done (design challenge, persona card, context analysis and objectives for the learning activity) so that they could use them as design principles for the next steps.

As part of our research design, participants were provided with a light form of guidance. The previous subsection showed one of the consequences thereof: participants resorted to what other participants had done to accomplish their own task. As a consequence, the fact that P1 - the participant with most page views created a protocol by adapting an existing set had a significant impact on the way the other participants drafted their protocols.

All protocols produced by the participants were based on the sets of heuristics that were provided as part of the learning materials. In the analysis of the form that these adaptations took, three formats emerged: the artefacts that are based on one of the set of heuristics provided, the artefacts that are a combination of heuristics from different sets, and the artefacts that are question-based. This classification is relevant as it shows different degrees of processing - and probably understanding - of the task. Thus, participants that took one existing set and selected heuristics from this single set showed the largest discrepancy between their heuristics and their design, as a pre-existing set of heuristics is by default as standard and generalisable as possible. On the other hand, the protocols that were based on a set of questions differed the most from the sets provided.

Table 6 provides an overall classification of the 33 protocols (out of 36) analysed. Three artefacts are not included for further analysis; one was an exact copy of a pre-existing set, another one included only the headings of the heuristics as in the sets provided, and the third one contained no heuristics (see last line of Table 6).

Table 6 Classification of heuristic protocols according to the format type

\begin{tabular}{llc}
\hline Type of protocol & Source of inspiration & No. of protocols \\
\hline Adaptation & Benson et al. (2001) heuristics & 10 \\
Adaptation & Ssemugabi \& de Villiers (2010) heuristics & 3 \\
Adaptation & A combination of the different sets of heuristics & 7 \\
& provided & 13 \\
Questions & A set of questions & 3 \\
Not analysed & Not a real heuristic protocol & \\
\hline
\end{tabular}

Heuristic protocols adapted from existing sets

Given the classification in Table 6, a total of 20 protocols fall into the "adapted from existing sets" category. Their authors chose to adapt an existing set of heuristics; they did so by maintaining the title of the heuristic and making variations in the sample questions for each heuristic. Figure 4 shows an example of this (protocol of P1). 
My Heuristics Evaluation Protocol for my Learning Design.

\section{Visibility of learning design (LD) status:}

- Is the learner guided in every step in detail, where to go and how to act?

- Are instructions rendered with clarity and precision?

- Is, at the beginning, caused embarrassment and confusion about how the learner to start his/her work?

- Is there continuous feedback so that he/she knows what to do?

- Seems clear that its is requested to engage in the process of understanding of the poet's life and then to approach the poetic creation with his/her experiential perspective?

\section{Match between learning design and the real world:}

- Does the LD use words, phrases, concepts familiar to the learner?

- Are the cognitive patterns of interface appropriate for the level of all personas created?

- Does the LD make learner understand that must perceive the poem through his/her thoughts, feelings and experiences?

- Are informations appeared in natural and logical order?

\section{User control and freedom:}

Does the LD allow the learner to understanding his mistakes and returning to the previous sections, so that start from the beginning?

\section{Recognition rather than recall:}

- Are instructions to use all the tools available and easily useable?

- Does the LD provide user-friendly and clear directions when the learner requests assistance?

Figure 4. Heuristic protocol of P1, first heuristics from her adapted set

Most participants applied a very simple approach as seen from the analysis of the selection of the specific heuristics they adopted. Table 7 lists all heuristics defined by the original authors (Benson et al., 2001; Ssemugabi \& de Villiers, 2010). It is important to notice that the order of the heuristics in these two existing heuristics sets marked the selection of heuristics that participants made. Thus, we can see how the first three heuristics are also the three most selected ones. Table 7 also notes whether a specific heuristic is part of the general usability criteria or part of the educational criteria. The order approach that participants followed as well as the first protocol (Figure 4) resulted in a predominance of usability heuristics over pedagogical heuristics. Note that, given that participants had not yet decided which ICT tool they would select for their learning activity, pedagogical heuristics are the more adequate for the task.

Table 7

Number of participants who selected a particular heuristic

\begin{tabular}{lllcc}
\hline $\begin{array}{l}\text { No. of } \\
\text { participants } \\
\text { who included } \\
\text { the heuristic }\end{array}$ & Type of heuristic & Title of heuristic & $\begin{array}{l}\text { Order of } \\
\text { heuristics by } \\
\text { Benson et al. } \\
\text { (2001) }\end{array}$ & $\begin{array}{l}\text { Order of } \\
\text { heuristics by } \\
\text { Villiers (2010) }\end{array}$ \\
\hline 17 & $\begin{array}{l}\text { General interface } \\
\text { usability criteria }\end{array}$ & $\begin{array}{l}\text { Match between the system and the } \\
\text { real world, i.e., match between } \\
\text { designer model and user model }\end{array}$ & 2 & 2 \\
\hline 17 & $\begin{array}{l}\text { General interface } \\
\text { usability criteria }\end{array}$ & User / learner control and freedom & 3 & 3 \\
\hline 14 & General interface & Visibility of system status & 1 & 1 \\
\hline
\end{tabular}




\begin{tabular}{|c|c|c|c|c|}
\hline & usability criteria & & & \\
\hline 13 & Educational criteria & Media integration & 15 & N/A \\
\hline 11 & $\begin{array}{l}\text { General interface } \\
\text { usability criteria }\end{array}$ & Recognition rather than recall & 6 & 6 \\
\hline 11 & $\begin{array}{l}\text { General interface } \\
\text { usability criteria }\end{array}$ & Flexibility and efficiency of use & 7 & 7 \\
\hline 11 & $\begin{array}{l}\text { General interface } \\
\text { usability criteria }\end{array}$ & Interactivity & 11 & N/A \\
\hline 10 & $\begin{array}{l}\text { General interface } \\
\text { usability criteria }\end{array}$ & Aesthetic and minimalist design & 8 & 8 \\
\hline 10 & $\begin{array}{l}\text { General interface } \\
\text { usability criteria }\end{array}$ & $\begin{array}{l}\text { Recognition, diagnosis, and } \\
\text { recovery from errors }\end{array}$ & 9 & 9 \\
\hline 10 & Educational criteria & $\begin{array}{l}\text { Resources - Support for } \\
\text { personally significant approaches } \\
\text { to learning }\end{array}$ & 16 & 16 \\
\hline 10 & $\begin{array}{l}\text { General interface } \\
\text { usability criteria }\end{array}$ & Feedback & 19 & N/A \\
\hline 8 & $\begin{array}{l}\text { General interface } \\
\text { usability criteria }\end{array}$ & Help and documentation & 10 & 10 \\
\hline 8 & $\begin{array}{l}\text { General interface } \\
\text { usability criteria / } \\
\text { Educational criteria }\end{array}$ & Content & 20 & N/A \\
\hline 8 & Educational criteria & $\begin{array}{l}\text { Learner motivation, creativity and } \\
\text { active learning }\end{array}$ & N/A & 20 \\
\hline 6 & $\begin{array}{l}\text { General interface } \\
\text { usability criteria }\end{array}$ & $\begin{array}{l}\text { Error prevention, in particular, } \\
\text { prevention of peripheral usability- } \\
\text { related errors }\end{array}$ & 5 & 5 \\
\hline 6 & Educational criteria & $\begin{array}{l}\text { Learning design ( } 2 \text { of the artefacts } \\
\text { referred to this as "Learning } \\
\text { Design Management") }\end{array}$ & 13 & N/A \\
\hline 6 & Educational criteria & $\begin{array}{l}\text { Clarity of goals, objectives and } \\
\text { outcomes }\end{array}$ & N/A & 13 \\
\hline 6 & Educational criteria & $\begin{array}{l}\text { Effectiveness of collaborative } \\
\text { learning (where such is available) }\end{array}$ & N/A & 14 \\
\hline 4 & Educational criteria & Assessment & 14 & N/A \\
\hline 4 & Educational criteria & $\begin{array}{l}\text { Feedback, guidance and } \\
\text { assessment }\end{array}$ & N/A & 18 \\
\hline 3 & $\begin{array}{l}\text { General interface } \\
\text { usability criteria }\end{array}$ & $\begin{array}{l}\text { Cognitive error recognition, } \\
\text { diagnosis and recovery }\end{array}$ & N/A & 17 \\
\hline 2 & $\begin{array}{l}\text { General interface } \\
\text { usability criteria }\end{array}$ & $\begin{array}{l}\text { Consistency and adherence to } \\
\text { standards }\end{array}$ & 4 & 4 \\
\hline 1 & $\begin{array}{l}\text { General interface } \\
\text { usability criteria / } \\
\text { Educational criteria }\end{array}$ & Message design & 12 & N/A \\
\hline 1 & Educational criteria & Learning management & 18 & N/A \\
\hline
\end{tabular}




\begin{tabular}{lllcc}
\hline 1 & Educational criteria & $\begin{array}{l}\text { Relevance of site content to the } \\
\text { learner and the learner process }\end{array}$ & N/A & 12 \\
\hline 1 & Educational criteria & $\begin{array}{l}\text { Context meaningful to domain and } \\
\text { learner }\end{array}$ & N/A & 19 \\
\hline 1 & Educational criteria & Level of learner control & N/A & 15 \\
\hline 0 & $\begin{array}{l}\text { General interface } \\
\text { usability criteria / } \\
\text { Educational criteria }\end{array}$ & Performance support tools & 17 & N/A \\
\hline 0 & $\begin{array}{l}\text { General interface } \\
\text { usability criteria }\end{array}$ & $\begin{array}{l}\text { Simplicity of site navigation, } \\
\text { organisation and structure }\end{array}$ & N/A & 11 \\
\hline
\end{tabular}

Heuristic protocols as a set of questions

As noted, the protocols based on questions represent a different trend in what participants did to define them. As with the previous protocols, these questions were also based on the set of heuristics provided. However, the question-based protocols differ more from the sets provided and the adapted protocols in several ways: the concept of a heuristic is understood as questions to assess the design with, the type of heuristics that the questions were based on as well as the number of rules of thumbs included. Figure 5 shows the protocol from the first participant to publish a question format in the discussion forum.

\begin{tabular}{|c|c|}
\hline \multicolumn{2}{|l|}{ Heuristic evaluation for my scenario } \\
\hline \multicolumn{2}{|l|}{ Questions of evaluation: } \\
\hline Questions & \begin{tabular}{l|l|l|l}
1 & 2 & 3 & 4
\end{tabular} \\
\hline \multicolumn{2}{|l|}{ Do you think this activity is attractive and interesting? } \\
\hline \multicolumn{2}{|l|}{ Do the participants understand what they have to do and why? } \\
\hline \multicolumn{2}{|l|}{ Is the given information enough and constant? } \\
\hline \multicolumn{2}{|l|}{ Do you think previous knowledge is required? } \\
\hline \multicolumn{2}{|l|}{ Is there enough communication between participants? } \\
\hline \multicolumn{2}{|l|}{ Is there enough communication with the teacher? } \\
\hline \multicolumn{2}{|l|}{ Does the procedure gives the opportunity to all the participants express their ideas? } \\
\hline \multicolumn{2}{|l|}{ Does the procedure encourages self expression, self action and take the initiative? } \\
\hline \multicolumn{2}{|l|}{ Is there enough use of ICT Tools? } \\
\hline \multicolumn{2}{|l|}{ Is the use of ICT Tools necessary in the proccedure? } \\
\hline \multicolumn{2}{|l|}{ Is there connection between the lesson and everyday life? } \\
\hline Do you thing the learning proccedure helps to achieve the aim of the lesson? & \\
\hline
\end{tabular}

Figure 5. Heuristic protocol of P5

Analysing the question-based protocols, we see how, in contrast with the adapted formats, the types of questions are more related to the design of the ICT-based learning activity than to the usability aspects. For example, mapping the questions to a heuristic statement from the existing sets we see that "Learner motivation, creativity and active learning" is the rule of thumb preferred by participants with questions (76.9\%) over those who adapted the heuristics (40\%).

\section{How their design thinking unfolded (Topic 2)}

The design task on heuristic evaluation was part of the Week 3 activities. Within the overall MOOC, Week 3 activities were perceived as more difficult than the rest (Figure 6). Therefore, the overall experience with the $\mathrm{HE}$ method was negative, which is confirmed by some of the comments in the discussion forums. As Table 8 
shows, participants expressed both their lack of understanding and their uncertainty with the produced artefact, independently of the type of artefact produced.

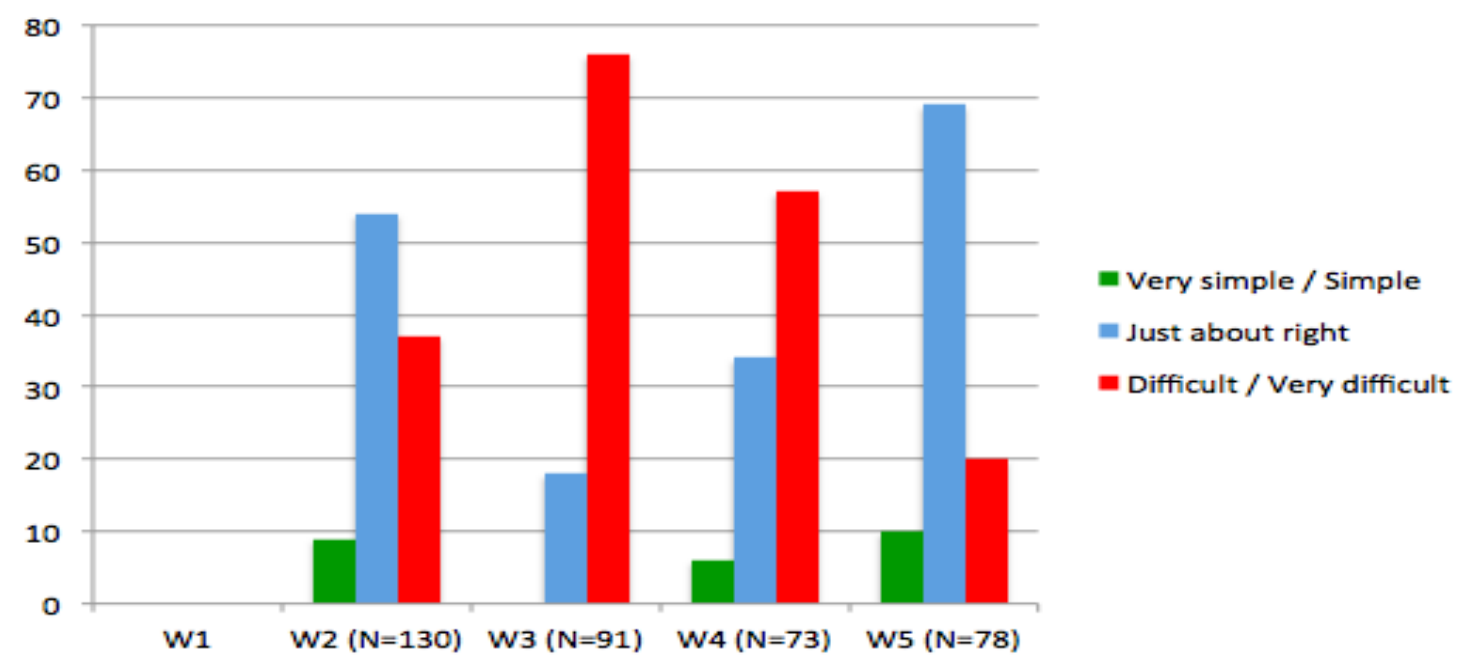

Figure 6. The level of difficulty of weekly activities, extracted from the questionnaires sent out weekly (in \%)

In contrast with this negativity, some qualitative data show positive attitudes towards the HE method. Table 8 shows indications that - mostly when reflecting on the task [LearnJ] (Table 2) - some participants saw the value of the heuristic evaluation method and thus understood its role in the design process.

Table 8

Coded participant comments and type of artefact produced

\begin{tabular}{|c|c|c|c|c|}
\hline Participant & Type & $\begin{array}{l}\text { Lack of } \\
\text { understanding of the } \\
\text { design task }\end{array}$ & $\begin{array}{l}\text { Uncertainty towards } \\
\text { the produced artefact }\end{array}$ & $\begin{array}{l}\text { Positive attitude towards the } \\
\text { HE method }\end{array}$ \\
\hline P1 & Adaptation & $\begin{array}{l}\text { "Define the Heuristics! } \\
\text { Very difficult issue as } \\
\text { to the exact wording of } \\
\text { my thoughts..." [+ text } \\
\text { copied from the task } \\
\text { activity] [LearnJ] }\end{array}$ & $\begin{array}{l}\text { "I updated my } \\
\text { Heuristic Evaluation } \\
\text { (especially in "Your } \\
\text { Task"). I do not know } \\
\text { if it is still correct." } \\
\text { [DisFor] }\end{array}$ & \\
\hline P3 & Adaptation & $\begin{array}{l}\text { "Professor is it possible } \\
\text { to explain us a little bit } \\
\text { more? Thanks anyway" } \\
\text { [DisFor] }\end{array}$ & $\begin{array}{l}\text { "Here is my Heuristic } \\
\text { evaluation protocol. Of } \\
\text { course I am not sure if } \\
\text { I did it right after } \\
\text { Professor's notice." } \\
\text { [DisFor] }\end{array}$ & $\begin{array}{l}\text { "In order to evaluate our learning } \\
\text { design and not to lose time and } \\
\text { be an effortful procedure, we use } \\
\text { heuristic evaluation. A useful } \\
\text { tool and we have to keep in mind } \\
\text { that the earlier you run an } \\
\text { evaluation activity on your } \\
\text { design the less costly it will be. } \\
\text { That is why evaluating soon and } \\
\text { often is highly recommended." } \\
\text { [DisFor] }\end{array}$ \\
\hline
\end{tabular}




\begin{tabular}{|c|c|c|c|c|}
\hline P5 & Questions & $\begin{array}{l}\text { “Activity } 13 \text { This was } \\
\text { complicated! Heuristics } \\
\text { really left me with a } \\
\text { headache.” } \\
\text { [DisFor] }\end{array}$ & $\begin{array}{l}\text { "I think an example } \\
\text { would have been useful } \\
\text { before this activity. } \\
\text { None of us seems to be } \\
\text { sure of the result." } \\
\text { [DisFor] }\end{array}$ & $\begin{array}{l}\text { "I liked it a lot, the subject is } \\
\text { really interesting and as a } \\
\text { theologist i can do like this, for } \\
\text { example, in the parable of the } \\
\text { good samaritan and how to show } \\
\text { love to others." } \\
\text { [DisFor] }\end{array}$ \\
\hline P6 & Adaptation & $\begin{array}{l}\text { "After a long struggle } \\
\text { with this activity I have } \\
\text { finally completed it.” } \\
\text { [DisFor] }\end{array}$ & $\begin{array}{l}\text { [PARTICIPANT'S } \\
\text { NAME, P23] thank } \\
\text { you for your comments } \\
\text {... we are all struggling } \\
\text { here ... and learning } \\
\text { from each other. I am } \\
\text { very happy to share my } \\
\text { work with others. I } \\
\text { think this is what this } \\
\text { seminar is about. } \\
\text { Creating usable } \\
\text { resources!!! } \\
\text { [DisFor] }\end{array}$ & $\begin{array}{l}\text { "I used my Heuristics Evaluation } \\
\text { Protocol combined with the } \\
\text { principles of the Cognitive } \\
\text { Walkthrough and Constructive } \\
\text { Interaction approaches which I } \\
\text { found most applicable to my } \\
\text { activity. The whole process } \\
\text { tested also my Heuristics which I } \\
\text { found very interesting." } \\
\text { [LearnJ] }\end{array}$ \\
\hline P7 & Questions & & $\begin{array}{l}\text { "To be honest I'm not } \\
\text { sure if this is what you } \\
\text { had in mind." } \\
\text { [DisFor] }\end{array}$ & $\begin{array}{l}\text { "Gone through the heuristics } \\
\text { material provided and think I got } \\
\text { the point. It's a great idea to } \\
\text { review learning designs before } \\
\text { you use them. It helps you avoid } \\
\text { designing mistakes.” } \\
\text { [LearnJ] }\end{array}$ \\
\hline P10 & Adaptation & & $\begin{array}{l}\text { "My Heuristic } \\
\text { evaluation - Activity } \\
\text { 13- related to a } \\
\text { scenario of a lesson in } \\
\text { my class is here. I } \\
\text { would appreciate the } \\
\text { feedback!! Thanks" } \\
\text { [DisFor] }\end{array}$ & $\begin{array}{l}\text { "The truth is that after all the } \\
\text { work I finally realised that I was } \\
\text { very happy with the outcome. } \\
\text { The evaluation is so much } \\
\text { important for a learning design } \\
\text { [...] it is then that you truly } \\
\text { understand what exactly you are } \\
\text { doing - what are your goals in } \\
\text { accordance with your design - if } \\
\text { what you ask is in accordance } \\
\text { with the context of your persona } \\
\text { or not?” }\end{array}$ \\
\hline
\end{tabular}

To further understand the position of the HE design task in the overall MOOC, Figure 7 shows the perceptions participants had for each activity separately (as the percentage of participants who gave a particular verdict). All perceived usefulness verdicts score over $80 \%$, including the heuristic design task. However, the heuristic design task has the lowest score at $84.6 \%$. To reinforce this picture, it is also the task that was most perceived as "not useful" or "kind of useful" (15.4\%). Thus, despite some positive comments towards the HE design task (Table 8), it resulted in little actionable knowledge. 


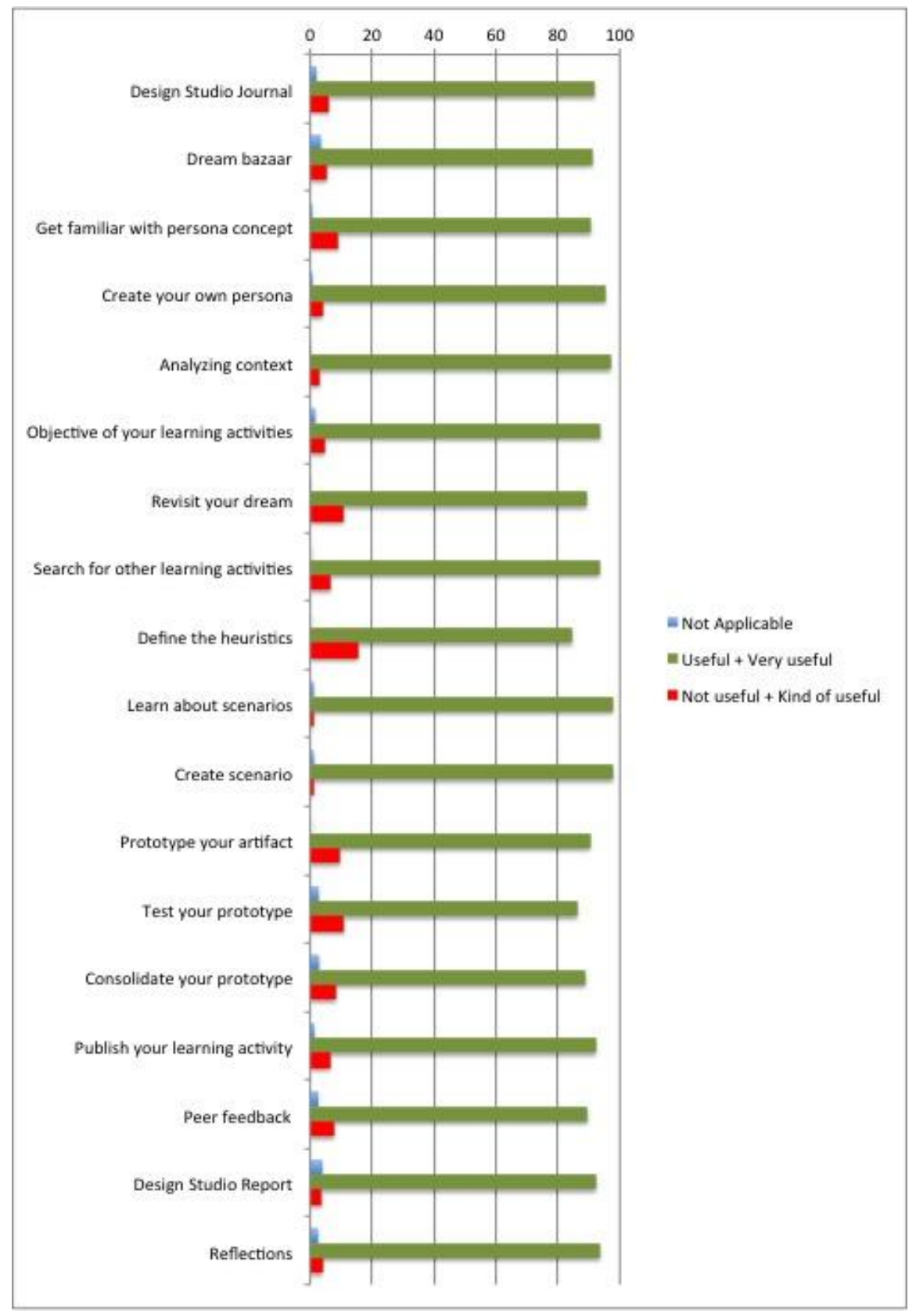

Figure 7. Answers to the level of usefulness of weekly activities (in \%). Bars indicate the percentage of participants providing a score of "not applicable", "very useful or useful", or "not useful or kind of useful". 


\section{Discussion, conclusions and design implications}

The theoretical research issue that triggered the present study is: Does the concept of heuristics and the method of heuristic evaluation provide actionable knowledge for design in education? To answer it, we opted for an empirical and exploratory methodology, working with educators and focusing on the "knowledge that is sufficient to inform action in the world” (Goodyear, 2015, p. 38). Within this context, the specific research question we set out to answer is: How does a design task based on the HE method perform in a realistic teacher training setting? We elaborated the question to encompass two topics: How do participants accomplish this task? (Topic 1) and How does their design thinking unfold? (Topic 2).

With respect to Topic 1 , we focused on the artefacts the participants produced and on how they did so. As indicated, the educational set-up purposely lacked teacher-led scaffolding; indeed, some participants may have seen the design task as internally inconsistent. The rationale for our choice lies in the research question. We intentionally left the approach open as heuristics - both educational and human-centred design ones may be used for a variety of different purposes. We summarise the approaches as ad hoc design principles versus the usage of existing heuristics. It is key to answering our research question to understand which one of these two approaches is more actionable.

The results indicate that, when confronted with a lack of guidance, participants opted for the existing heuristics approach: most participants based their own heuristics productions on the existing sets of heuristics provided, and/or on the artefacts that their fellows shared in the discussion forum. We assume that it is their expressed lack of understanding of the task or its perceived difficulty that lead participants to select and adapt existing heuristics rather than create novel ones from scratch.

The analysis of the heuristic evaluation protocols produced also shows that general usability-interface criteria prevail over educational ones. The reason may be that the participants were asked to design an ICT-based learning activity. Another explanation could reside in the practice-driven approach that educators use when designing for learning, together with the concept of pedagogical knowledge-in-pieces (Goodyear, Markauskaite, \& Kali, 2009). However, a more in-depth analysis led us to distinguish between three types of protocols created. Some participants selected and adapted their heuristics from a single set of the ones provided; others preferred to choose from different sets and subsequently adapt protocols. Yet others admittedly a few only - produced a set of questions themselves. Though these participants also started with the existing sets of heuristics, they diverged more from them than did the others. Interestingly, their protocols also included more educational design heuristics. Arguably, this group had the deepest understanding of the heuristic evaluation knowledge that was provided to them and, subsequently, made the best use of it.

And how did the participants' design thinking develop over time? (See Topic 2.) To tackle this question, we analysed the comments and reflections in the discussion forum and the learning journals. We defined three themes that include the chronological order in the unfolding of the participants' design thinking: lack of understanding of the design task, uncertainty towards the artefact produced, and finally a positive attitude towards the HE method. The results show that the perceived level of difficulty - both in understanding and producing - can be counterbalanced by some positive comments towards the value of the heuristic evaluation method.

Despite these two positive signs - that is, the emergence of question-based protocols under Topic 1 and the positive attitude towards HE under Topic 2 - we cannot but conclude that neither the setting (the HANDSON MOOC) nor the design task as it was formulated allowed educators to leverage the purported advantages of HE to the full (first conclusion). To them, HE knowledge was actionable only to a limited extent. Perhaps, the word "heuristic" was more of a barrier to comprehension than we anticipated. The same task under the heading of "design principle" or "rule of thumb" may have lowered their perception of difficulty. The rest of the human-centred design methods implemented in the epistemic design of the MOOC did not involve such domain-specific wordings. Is that why these did not generate this combined perception of high difficulty and low usefulness? Clearly, more research is needed here. Furthermore, we likely have witnessed a first-mover 
effect. The first protocol published probably set an example that many other participants chose to follow, perhaps preventing them from investing more in devising protocols of their own making. Finally, our choice to leave the approach to the formulation of heuristics open, that is, to do away with scaffolding completely, may have proved too hard on many participants, however sensible our choice may have seemed at the outset. So, the provision of scaffolds, from using existing protocols to devising new ones de novo, may prompt the desired effect of using HE principles as actionable knowledge.

Remember that HE is considered to be easy to learn, efficient, and time- and cost-effective (Albion, 1999; Nielsen \& Mack, 1994; Ssemugabi \& de Villiers, 2010). So, there is every reason to try and capitalise on the benefits that HE has to offer, particularly in the present day and age. The almost constant cutting of education budgets (e.g., Goodyear, 2015), the push for technology in education (Dubos, 2013) as well as the day-to-day reality of most educators (Bennett et al., 2015, 2016) calls for design methods that are low-cost, efficient and easy to apply. Our research may indicate a steep HE learning curve for educators, but that does not need to detract from HE's potential as a design tool. Besides, we believe that HE would also facilitate the reuse of existing learning resources as promoted by learning design field (Laurillard, 2012) as well as the assessment of one's own learning activities, as redesign is part of a continuous cycle of improvement (Bennett et al., 2015).

Drawing on the general knowledge that is available about heuristic evaluation, we still advocate HE as part of a design process that covers the entire teaching-learning lifecycle (Goodyear, 2015). But keeping in mind the results we presented here, we suggest that within this lifecycle HE may be of good use if the following practices are followed:

- $\quad$ Start with educational heuristics only. In the process of designing an ICT-based learning activity, provide educators with heuristics that focus solely on the learning design aspects. This knowledge of powerful design heuristics can also increase the efficiency and effectiveness of educators' design work (see also McKenney et al., 2015).

- Include an initial heuristic evaluation task. In our study, educators were asked to define their own heuristics. To reduce the apparent difficulty of this task, educators should first use existing educational heuristics to assess learning activities (scaffolding).

- Promote a question approach for the de novo creation of heuristics. Similar to the human-computer interaction method of "cognitive walkthrough" (Nielsen \& Mack, 1994), educators seemed more comfortable reflecting through questions than through statements. This is aligned with the idea that the formulation of a question is key to the teacher inquiry process (see also Hansen \& Wasson, 2016).

- Bring in user interface/usability heuristics at a later stage only. Once educators have worked on the goals and heuristics of their learning activity, they are more ready to move to the ICT part. Usability heuristics can then become a tool to assess existing technology.

Our study extends and enhances the existing pool of empirical research on how to build on teacher expertise to support teachers in their design efforts; it examines the use of human-centred design methods to empower the design capacity of educators and informs both practice and research in the fields of learning design. In other words, it fits with the idea that "the future progress in learning design $R \& D$, [which] will require more and better research on users, their needs, contexts of use and the affordances of the various tools and resources that are meant to improve their design activity” (Kali et al., 2011, p. 130). If anything, our study supports a call for the creation of more (and better) links between human-centred design and learning design.

\section{Acknowledgements}

The first and third authors want to thank the HANDSON team for their productive collaboration. The HANDSON project (531086-LLP-1-2012-1-ES- KA3-KA3MP) has been funded with support from the Lifelong Learning Programme of the European Commission. The second author's contribution has been supported by TIN2014-53199-C3-3-R, MDM-2015-0502, and RecerCaixa CoT projects. 


\section{References}

Agostinho, S., Bennett, S., Lockyer, L., \& Harper, B. (2011). The future of learning design. Learning, Media \& Technology, 36(2), 97-99. https://doi.org/10.1080/17439884.2011.553619

Albion, P. R. (1999). Heuristic evaluation of educational multimedia: From theory to practice. In H. Goss (Ed.), 16th Annual Conference of the Australasian Society for Computers in Learning in Tertiary Education (pp. 9-15). Retrieved from http://www.ascilite.org/conferences/brisbane99/papers/albion.pdf

Asensio-Pérez, J. I., Dimitriadis, Y., Pozzi, F., Hernández-Leo, D., Prieto, L. P., Persico, D., \& VillagráSobrino, S. L. (2017). Towards teaching as design: Exploring the interplay between full-lifecycle learning design tooling and teacher professional development. Computers and Education, 114, 92-116. https://doi.org/10.1016/j.compedu.2017.06.011

Beale, R., \& Sharples, M. (2002). Design guide for developers of educational software. Canley: British Educational Communications and Technology Agency (BECTA).

Bencze, L., \& Hodson, D. (1999). Changing practice by changing practice: Toward more authentic science and science curriculum development. Journal of Research in Science Teaching, 36(5), 521-539. https://doi.org/10.1002/(SICI)1098-2736(199905)36:5<521::AID-TEA2>3.0.CO;2-6

Bennett, S., Agostinho, S., \& Lockyer, L. (2015). Technology tools to support learning design: Implications derived from an investigation of university teachers' design practices. Computers \& Education, 81, 211220. https://doi.org/10.1016/j.compedu.2014.10.016

Bennett, S., Agostinho, S., \& Lockyer, L. (2016). The process of designing for learning: understanding teachers' design work. Educational Technology Research and Development, 65(1), 125-145. https://doi.org/ 10.1007/s11423-016-9469-y

Benson, L., Elliott, D., Grant, M., Holzschuh, D., Kim, B., Kim, H., ... Reeves, T. (2001). Heuristic evaluation instrument and protocol for e-learning programs. Retrieved from http://treeves.coe.uga.edu/edit8350/HEIPEP.html

Boschman, F., McKenney, S., \& Voogt, J. (2014). Understanding decision making in teachers' curriculum design approaches. Educational Technology Research and Development, 62(4), 393-416. https://doi.org/10.1007/s11528-016-0078-8

Braun, V., \& Clarke, V. (2006). Using thematic analysis in psychology. Qualitative Research in Psychology, 3(2), 77-101. https://doi.org/10.1191/1478088706qp063oa

Brown, M., \& Edelson, D. C. (2003). Teaching as design: Can we better understand the ways in which teachers use materials so we can better design materials to support their changes in practice? Evanston, IL: The Center for Learning Technologies in Urban Schools. Retrieved from http://www.inquirium.net/people/matt/teaching as design-Final.pdf

Creswell, J. W. (2009). Research design: Qualitative, quantitative and mixed approaches (3rd ed.). Thousand Oaks, CA: Sage.

Dalziel, J., Conole, G., Wills, S., Walker, S., Bennett, S., Dobozy, E., ... Bower, M. (2016). The Larnaca declaration on learning design. Journal of Interactive Media in Education, 2016(1), 1-24. https://doi.org/10.5334/jime.407h

Doyle, W., \& Ponder, G. A. (1977). The practicality ethic in teacher decision-making. Interchange, 8(3), 112. https://doi.org/10.1007/BF01189290

Ertmer, P. (1999). Addressing first- and second-order barriers to change: Strategies for technology integration. Educational Technology Research and Development, 47(4), 47-61. https://doi.org/10.1007/BF02299597

Garreta-Domingo, M., Sloep, P., Hernández-Leo, D., \& Mor, Y. (2017a). Design for collective intelligence: Pop-up communities in MOOCs. AI \& Society, 1-10. https://doi.org/10.1007/s00146-017-0745-0

Garreta-Domingo, M., Sloep, P. B., Hernández-Leo, D., \& Mor, Y. (2017b). Editorial: Learning design for teacher professional development. International Journal of Educational Technology in Higher Education, 14(36), 19-21. https://doi.org/10.1186/s41239-017-0074-x

Goodyear, P. (2015). Teaching as design. HERDSA Review of Higher Education, 2, 27-50. Retrieved from http://www.herdsa.org.au/wp-content/uploads/HERDSARHE2015v02p27.pdf 
Goodyear, P., \& Carvalho, L. (2014). Framing the analysis of learning network architectures. In L. Carvalho \& P. M. Goodyear (Eds.), The architecture of productive learning networks (pp. 48-70). London: Routledge Falmer.

Goodyear, P., Markauskaite, L., \& Kali, Y. (2009, December 10). Learning design, design contexts and pedagogical knowledge-in-pieces. Paper presented at the Future of Online Learning Conference, University of Wollongong. Retrieved from http://ro.uow.edu.au/cgi/viewcontent.cgi?article=1001\&context=fld

Hansen, C. J., \& Wasson, B. (2016). Teacher inquiry into student learning: The TISL heart model and method for use in teachers’ professional development. Nordic Journal of Digital Literacy, 10(1), 24-49. https://doi.org/ 10.18261/issn.1891-943x-2016-01-02

Hernández-Leo, D., Asensio-Pérez, J. I., Derntl, M., Prieto, L. P., \& Chacón, J. (2014). ILDE: Community environment for conceptualizing, authoring and deploying learning activities. In S. De Freitas, C. Rensing, T. Ley, \& P. J. Muñoz-Merino (Eds.), EC-TEL 2014. LNCS (Vol. 8719, pp. 490-493). Heidelberg: Springer. https://doi.org/ 10.1007/978-3-319-11200-8_48

Hoogveld, A., Paas, Jochems, W., \& Van Merriënboer, J. (2002). Exploring teachers’ instructional design practices from a systems design perspective. Instructional Science, 30(4), 291-305. https://doi.org/10.1023/A:1016081812908

Janssen, F., Westbroek, H., Doyle, W., \& Van Driel, J. (2013). How to make innovations practical. Teachers College Record, 115(7), 1-42. https://doi.org/ 10.1016/j.tate.2011.07.003

Kali, Y., Goodyear, P. M., \& Markauskaite, L. (2011). Researching design practices and design cognition: contexts, experiences and pedagogical knowledge-in-pieces. Learning, Media and Technology, 36(2), 129-149. https://doi.org/10.1080/17439884.2011.553621

Laurillard, D. (2012). Teaching as a design science: Building pedagogical patterns for learning and technology. London: Routledge.

Markauskaite, L., \& Goodyear, P. (2009). Designing for complex ICT-based learning: Understanding teacher thinking to help improve educational design. In R. J. Atkinson \& C. McBeath (Eds.), Same Places Different Spaces. Proceedings of the 26th Annual ascilite International Conference (pp. 614-624). Auckland: The University of Auckland, Auckland University of Technology, and Australasian Society for Computers in Learning in Tertiary Education. Retrieved from http://www.ascilite.org/conferences/auckland09/procs/markauskaite.pdf

Matuk, C. F., Linn, M. C., \& Eylon, B. S. (2015). Technology to support teachers using evidence from student work to customize technology-enhanced inquiry units. Instructional Science, 43(2), $229-257$. https://doi.org/10.1007/s11251-014-9338-1

McKenney, S., Kali, Y., Markauskaite, L., \& Voogt, J. (2015). Teacher design knowledge for technology enhanced learning: An ecological framework for investigating assets and needs. Instructional Science, 43(2), 181-202. https://doi.org/10.1007/s11251-014-9337-2

Mor, Y., \& Mogilevsky, O. (2013). The learning design studio: Collaborative design inquiry as teachers’ professional development. Research in Learning Technology, 21(1), 1-15. https://doi.org/10.3402/rlt.v21i0.22054

Mor, Y., Derntl, M., Hernández-Leo, D., Craft, B., Pozzi, F., Persico, D., ... Retalis, S. (2011). The learning design grid. Retrieved from http://www.ld-grid.org/resources/methods-and-methodologies/heuristic-evaluation/

Nielsen, J., \& Mack, R. L. (1994). Usability inspection methods. New York, NY: John Wiley \& Sons.

Orlikowski, W. J., \& Baroudi, J. J. (1991). Studying information technology in organizations: Research approaches and assumptions. Information Systems Research, 2(1), 1-28. https://doi.org/10.1287/isre.2.1.1

Penuel, W. R., \& Gallagher, M. S. (2009). Preparing teachers to design instruction for deep understanding in middle school earth science. Journal of the Learning Sciences, 18(4), 461-508. https://doi.org/10.1080/10508400903191904

Quinn, C. N. (1996). Pragmatic evaluation: Lessons from usability. In A. Christie (Ed.), Proceedings of the 13th Annual Conference for the Australasian Society for Computers in Learning in Tertiary Education. Adelaide: University of South Australia. Retrieved from http://www.ascilite.org/conferences/adelaide96/papers/18.html 
Reeves, T. C., Benson, L., Elliott, D., Grant, M., Holschuh, D., Kim, B., ... Loh, C. S. (2002). Usability and instructional design heuristics for e-learning evaluation. In P. Barker \& S. Rebelsky (Eds.), World Conference on Educational Multimedia, Hypermedia and Telecommunications (pp. 1615-1621). Waynesville, NC: AACE. Retrieved from https://www.learntechlib.org/j/EDMEDIA/v/2002/n/1/

Ssemugabi, S., \& de Villiers, R. (2007). A comparative study of two usability evaluation methods using a web-based e-learning application. In L. Barnard \& R. A. Botha (Eds.), Proceedings of the 2007 annual research conference of the South African Institute of Computer Scientists and Information Technologists on IT Research in Developing Countries (pp. 132-142). New York, NY: ACM. https://doi.org/10.1145/1292491.1292507

Ssemugabi, S., \& De Villiers, M. R. (2010). Effectiveness of heuristic evaluation in usability evaluation of elearning applications in higher education. South African Computer Journal, 45(July), 26-39. https://doi.org/10.18489/sacj.v45i0.37

Stake, R. E. (2010). Qualitative research: Studying how things work. London: The Guilford Press.

Corresponding author: Muriel Garreta-Domingo, murielgd@gmail.com

Australasian Journal of Educational Technology @ 2018.

Please cite as: Garreta-Domingo, M., Hernández-Leo, D., \& Sloep, P. B. (2018). Evaluation to support learning design: Lessons learned in a teacher training MOOC. Australasian Journal of Educational Technology, 34(2), 56-77. https://doi.org/10.14742/ajet.3768 